\title{
The Hundreds of Domesday
}

\section{THE HUNDRED OF LAND.}

THEE occasional mention in Domesday Book of hides in Leicester1 shire has long been a stumbling-block to students of the great survey. The obvious explanation that these hides in a county assessed by carucates meant land newly brought into cultivation, which Mr. Eyton believes to be the meaning of the carucate in the hidated counties, ${ }^{1}$ is excluded by the language of the Domesday entries. Mr. Eyton was puzzled by these Leicestershire hides, ${ }^{2}$ and another eminent Domesday student, Mr. J. H. Round, merely says that ' the formulae in that county appear to be very peculiar,' s and attempts no explanation of the passages. I venture to suggest that these Leicestershire hidae are not hides at all, but hundreds. In the survey the abbreviation $l d d$ stands for hundred, ${ }^{4}$ and it is fair to presume that it was so.used in the original returns. ${ }^{5}$ The scribe who entered these returns in the Domesday Book probably extended the abbreviation as lide instead of hundred in this case, becanse Leicestershire is the first county in the Domesday order in which the peculiar hundreds here intended are mentioned.

The hundreds here referred to are not the administrative handreds, but the small hundreds of twelve geld carucates, which it may be convenient provisionally to describe as 'manorial hundreds.' These hundreds, which have,been often identified by English writers with the administrative hundreds, are well defined in the Rutland Survey ('D. B.' i. fo. $293 \mathrm{~b}$, col. 1) : In Alfindestou Wapent. sunt ii. lundrez; in unoquoque xii. carucatae ad geldum, et in unoquoque

I Aralysis of the Dorset Survey, p. 17; Analysis of the Staffordshire Survey, p. 24. See also Mr. Ronnd, in Domesday Strudies, i. 105.

Stafordshire Survey, p. 24.

- Domesday Studies, i. 204.

- Hundred is written ' hd' frequently in i. 876a. The abbreviation is common throughout the survey. Bee especislly the Northamptonshire and Warwickshire surveys, which precede and follow Leicestershire.

5 The scribe of the Inquivitio Elionsis eems to have made the opposite mistake of writing hurdred instead of hide in the cases of Waratinge (500b) and Melebarna (502b), where Domesday has in the same passages (i. 190b, col. 2 ; 191b, col. 1) hictes. The Inquisitio has hund' instead of hid' at 505a, Wittleseia defend[abat] se T. $R$ Eadwardi pro vi. hurd. . . . De his vi. h. tonot $S$. Aedel[dreda] ii. I. In Domasddy, $191 b$, col. 2, the posset.ions of Ely in 'Witesie ' (Whittleses) are described 'ii. hid.' 
xxiiii. carucae esse possunt. . . . In Martinesleie Wap. est i. hundret, in quo xii. caruc[atae] terrae ad geldum; et xlviii. carucae esse possunt. As these entries only agree in stating that the hundred contained twelve geld carucates, ${ }^{6}$ we may assume that this is the mesning of the manorial hundred. The definition is sapported by the invaluable survey of Lincolnshire dating from the early part of the twelfth centary. ${ }^{7}$ In this sarvey the wapentakes are regularly divided into hundreds, and the contents of the handreds are sometimes given. Thus, fo. 8, In Haxeholm habentur iiii. $h[$ undreda,] in uno quoque xii. c[arucatae] terrae; In Welle Wap. habentur vii. hundr[eda, in unoquique xii. carncatae terrae. The same contents are given to the hundreds in Walescroft (fo. 9), Hawardeshou (fo. 11), Bredelai (fo. 13), Ludeburc (fo. 15), Ierburc (ibid.), Calswat (fo. 20), Wragehou (fo. 21), Hilla (fo. 23), Ludesc (fo. 24), and Horncastra wapentakes (fo. 26). Moreover, at fo. 19, a fee amounting, according to the particulars, to 41 carucates and 14 bovates (that is, 42 car. and 6 bovetes), is described as containing 3 hundreds $(3 \times 12=36)$ and 6 carucates and 6 bovates. Again, at fo. 23 a fee amounting to 39 car. and 20 bovates (that is, 41 car., 4 bovates) is reckoned as 3 hundreds, 5 carucates, and 4 bovates. ${ }^{8}$ According to Mr. Waters, this survey mentions, in Lincolnshire, 1,912 caracates and 2 bovates. Divided by twelve, this gives 159 hundreds. The survey specifies 187, exclusive of the number in the large wapentake of Manley, the particulars of which are not preserved; ${ }^{\theta}$ so that the county was systematically divided into these hundreds.

Some of the hundreds of this later survey appear in Domesday as sokes. Of the foe of the earl of Chester ten carucates in Lecheburna Soca ('D. B.' i. 349a, col. 1) appear as 10 car. in hundr[edo] de Lecheburna in the later survey (fo. 20); the twelve carucates in Suabi et Elgelo et Toresbi et Clactorp et Totele Soas ('D. B.' ibid.) are in hundr[edo] de Suabi xii. c[arucatae] in the loter survey. Geoffrey

- Kelham, Domesday Book Illustrated, p. 169, quotes Caricatas terras (12) faciunt i. hidam, but gives no reference. If derived from Domesday, it mast refor to these Rutland entries. The passage has been, rather unfortunately, oopied from Todd into the Now English Dictionary, s.v. ' Caracate.'

'MJ references are to the facsimile edition of this survey published by Mr. Greenstreet in 1884 . He assigns the survey to between 1101 and 1109 , or, at the outeide, 1119. Mr. Chester Waters had previously deted it between 1114 and 1116, in the Trareactions of the Associated Architectural Bociotics, vol. xvi. 1889.

- At fo. 20 a foe of 47 carucates and 14 bovates (that is, 48 carncetes 6 bovates) is reckoned by some error as 4 hondreds and 10 bovates.

- A discrepancy no doubt arose trom the wapentakes being divided into handreds, some of which did not quite contain 12 orruastes. Ladborough wapentake containing 86 aracates is correotly described as 8 hondreds, but the 10 handreds of Louth Eske contained only 119 carucstes 4 bovates, whilat the 14 hnndreds of Yarborough wapentake contenined 171 cerrucates $1 \frac{1}{8}$ bovete instead of 178 asrucetes. Similarly the 6 hundreds of Gartree wapenteke contained 75 carucates 2 bovates, whilst Bradley wapentake with 78 carucates 4 bovates only contained Bf handreds and 3 bovates, and Aslacoo wapentake with 104 carucates $4 \frac{1}{8}$ bovates was divided into 7 handreds. 
de la Wirce granted the hundred of Crowle to Selby abbey shortly after the completion of Domesday. He describes it as Crull, scilicet hundredum terrae cum tota soca et saca ut in uicecomitatu Lincolnice iacet. ${ }^{10}$ Bat the fact that the hundred consisted regularly of twelve geld carucates suggests that the division was really a fiscal one, and therefore the identification of a hundred with $\mathrm{a}$ soke is accidental. In the later survey, fo. 20, the lands of the earl of Chester, lying in at least five hundreds, are divided, irrespectively of their situation, into four hondreds, and ten carucates. There is a similar division at fo. 23.

It may be necessary to explain, before analysing the Leicestershire ' hides,' that in Domesday the value of a manor is estimated in three ways. The first is the number of ploughlands at which the manor is assessed for geld. This is the lida ad goldum of the south and the carrcata ad geldum of the north. The assessment generally varied from the actual number of ploughlands in the manor, which are nsually given in Domesday. The real ploughlands are distinguished as terrae ad caricas." In addition to these details, we have the number of ploughteams recorded. These again frequently differ from the number of plonghlands. In exceptional cases, as in Anlepe, Leicestershire (i. fo. 231b, col. 2), all three sets of figures agree. More often the assessment for geld agrees with the number of plonghlands in the manor.

We will now proceed to the Leicestershire hides. In vol. i., fo. 236n, col. 1, we read: Ogerus Brito tenet in Cilebe de rege ii. partes unizcs lidae, id cst xii. car[ucatae] terrae. We are, I think, justified in treating the gloss as defining the hida=hundred. Tro-thirds of a hundred of twelve carucates are eight carucates. This is precisely the number of ploughlands recorded as being in the manor in King Edward's time (Ibi fuernent viii. car[ucatae])..$^{12}$ At the time of the survey there were, however, only six teams on the manor. In Wichingestone, fo. 232a, col. 1 , there were one ' hide' and the third of another. This, on my suggestion, means sixteen carucates. This was precisely the number of ploughlands in the manor, which were cultivated by seventeen teams. Moreover, wo learn that the demesne consisted of a third of a 'hide,' i.e. four carn-

10 Monasticon Anglicanum, iii. 149. In John'e canfirmatory charter, L.D. 1204, it is described as Crull', scilicet unum hundr' in uicecomitatu Linc. Rot. Chart. 121a.

"The ploughlands are very frequently omitted in the Leicester survey. Are we to assume that in esses of omission they agreed in number with the geld caracstes?

12 This and similar entries in Leicestershire are very puzzling. It is impossible to determine whether they mean geld caracates, actual ploughlands, or merely plough teams. Mr. Ronnd, Domesday Studies, i. 204, considers car' to mean in these crses ploughlands. If it be read carucata, we must conclude thet the terms of assessment had been changed ainoe the death of the Confessor. But the word is frequently followed by details of the number of the ploughs at the time of sarvey, which seem to be contrasted with these entries concerning the time of King Edward. So that after all carvea-ploagh team may be the mesning of this formale. 
cates. It was tilled by four teams. This case seems to strongly support my theory. In Ailestone, fo. $291 b$, col. 1 , there were $1 \frac{1}{6}$ of a 'hide,' i.e. fourteen caracates. I am again supported by the survey, which says there were there fourteen car[ucates] in king Edward's time, although at the time of the survey there were only seven teams..$^{13}$ But if the six ploughlands held by Saxi are to be counted, there were at least thirteen plonghlands. In Brandinestor, fo. 237a, col. 2, we read : Ibi sunt ii partes unius lidae, id est xii. car[ucatae] terrae. Here, as in Cilebe, we have the 'hide'= hundred defined as twelve carucates, but the evidence in support of the suggested reading is not so clear as in the Cilebe case. We should expect in Brandinestor eight carucates. There were, however, only six car[ucates] there in Edward's time. At the time of the survey there were five teams, and, in addition, three carucates tilled by one team. Thus there seems to hare been really eight ploughlands in the manor. In Cnihtetone, fo. 281a, col. 1, there were two parts of a 'hide,' i.e. eight carucates, but there were only six ploughlands tilled by six teams. Precisely the same figures occur in Cnapetot, fo. 231b, col. 1. In Fostone, fo. 235a, col. 2, the helf-' hide' (six carucates) contained only fire ploughlands worked by, apparently, seven teams. In the next entry,

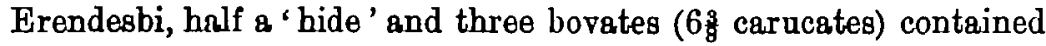
seven ploughlands, and were tilled by seven teams. Here the discrepancy is not very great. In Setintone, fo. $230 b$, col. 1, there was one 'hide', minus one carucate, i.e. eleven carucates. The number of ploughlands is not given, the teams numbering nine. In. Dislea, ibid. col. 2, there was one 'hide' (twelve carucates) worked by eight teams, the number of ploughlands not being given. Half a 'hide' and one carncate, i.e. seven carucates, at Westham, fo. 237a, col. 2, was six car[ucates] in Edward's time. At the time of the survey they were tilled by seven terms. Saltebi (fo. 234b, col. 2) was assessed at two 'hides' and three carucates $(=27$ carucates). In the time of hing Edward there were there twentyeight car[ucates], and at the time of the survey it was cultivated by twenty-six teams.

The fact that the actual number of ploughlands falls short of the assumed number of carucates in some of the above instances is not fatal to my hypothesis, for in Leicestershire there are several instances where the carucates exceed the ploughlands. For example, in Chenemundescote, fo. 231a, col. 1, there were thirteen and a half carucates, but only eight ploughlands and five teams; in Walecote, on the same page, there were six carucates to three ploughlands and three teams; in Stoctone, 232a, col. 1, there were twenty-eight carucates against twenty-two ploughlands and twenty-

1) Similarly 13 ceracstes at Terlintone, fo. $280 \mathrm{~b}$, col. 2, were cultivated by only nine teams, and the 8 carucates in Lubanham by five teams. 
five teams. But such instances of apparently excessive assessment will not explain the Duntone entry, fo. 236a, col. 1. Here there were three 'hides' (thirty-six carucates), but only six ploughlands. No teams are mentioned. But there was something abnormal in this holding; for it had gone down in value from 208. to 28. and was ' waste' when the holder received it. There is an entry of a ' hide' in Burtone, a soke of Loughborough (fo. 237a, col. 1), of which the only details given are that there was one team in demesne.

The manor of Burbece (i. 231a, col. 2), the property of Coventry abbey, appears to be an instance of 'beneficial hidation,' i.e. the assessment had been reduced by royal grant. It was assessed at one and a quarter hides, that is, fifteen carucates, although it contained twenty-two and a half ploughlands. The survey only specifies ten teams in spite of the fact that the manor had increased enormously in value.

The case of Medeltune, fo. $235 b$, col. 1, is puzzling. We read : Ibi sunt vii. hidae et una carucata terrae et una bouata : in una quaque hida sunt xiiii. carucatae terrae et dimidia. This reveals, again assuming lida to mean hundred, a larger hundred of fourteen and a half carucates. Apart from my theory, it is obvious that the contents of this manor were $102 \frac{1}{\mathrm{~s}}$ carucates and one bovate. In Medeltune itself there were only ten and a half teams. The members of the menor conteined in Edward's time forty-eight car[acates], whilst at the survey there were forty-three ploughs. The entry is as incomprehensible as the Loughborough one (297a, col. 1). ${ }^{4}$ The larger hundred of fourteen and a half carucates here mentioned may possibly be intended in the Bladi entry, 237a, col. 2. Here there were half $\mathrm{a}$ ' $h$ hide' and one and a half carucates, but in L'dward's time there were there nine car[ucates]. With the larger hundred we should get eight and three-quarter carucates, agreeing very nearly with the contents in the Confessor's time. With the smaller hundred, we have seven and a half carucates, agreeing approximately with the seven ploughteams in existence when the survey was taken. In Scepeshefde, fo. $290 b$, col. 2, two and a half hides and four carncates were worked by thirty-eight ploughteams. The assessment is here thirty-six and a quarter carucates by the larger hundred, or thirty-four by the smaller one.

The above exhausts the list of 'hides' mentioned in the Leicestershire Survey, and there is, I contend, nothing in them that conflicts with the suggestion that hida is a mistake for 'hundred.'

14 Mr. Pell, with his usasl freedom trom the trammels of facts, airily explains the Medeltane entry in Domesday Studies, i. pp. 187, 323, by the simple process of treating the caruastes as virgates, and then making the virgate so obteined a tenth of the hide instead of the fourth. In other words, he makes the carucate into the tenth of its areal equivalent the bide. 
A reference to one of these small hundreds may be, I think, detected in Derbyshire. In Domesday, i. fo. $273 a$, col. 2, occurs the title Morelestan Wap. Salle Hd. This is just the way in which these hundreds are entered in Lincolnshire. We find that the bishop of Chester had in Salle (Bawley) and two berewicks twelve carucstes ad geldum, the exact contents of the hundred. In Aitone (Long Eaton), which follows under the same heading, he had twelve more carucates. This is probably another hundred. The transcriber appears to have omitted the heading Aitone $H d$., as, indeed, he has apparently done in every case except that of Sawley. He has even omitted the name of the wapentake before the next entry to Long Eaton, whereby the manor of Bubedene, which was really in Appletree wapentake, is made to appear in Morley wepentake at the other extreme of the county. There are other instances in the survey where the scribes, by omitting the names of the wapentakes or hundreds in codifying the holdings under the owners' names, have caused a manor to appear in a wrong division of the county. In the Nottinghamshire survey Blidsoorde $H d$. is written against the entry of Alwoldestorp (i. 291a, col. 1), just as the hundreds are entered in Lincolnshire. In the Notts survey this position is frequently occupied by soka or berewica. Hundreds are mentioned in Notts at i. 291a, col. 1, where we read that five sokemen in aliis hundret pertained to the manor of Aigrun; at Lecche (291b, col. 2), a berewic that pertained to Pluntre Hundred; and at Farnesfeld $(288 b, \mathrm{col} .2)$, where we are told that the soke of one bovate pertained to Bouthwell and of the other belonged to the king, sed tamen ad hund. de Sudwelle pertinet. These details are essentially manorial, and seem to argue that these Notts hundreds are also manorial hundreds. The Farnesfeld entry is supported by the statement at $283 a$, col. 1 , that in Suduuelle numerantur $x x$. bereuu[icae $]$.

In a future paper I hope to be able to throw further light upon these hundreds, which were not restricted to the three counties here dealt with.

W. H. Stetenson. 